\title{
KEDUDUKAN MAZHAB SYAFI'I DALAM UNDANG-UNDANG JENAYAH ISLAM DI MALAYSIA
}

\author{
Oleh: \\ Paizah Haji Ismail*
}

\begin{abstract}
Despite the fact that there is no provision which stipulates the preference of any mazhab or school of fiqh in the implementation of Islamic criminal law in Malaysia, past or present, the use of the views of the Shafit ie school is always preferred. The reason behind it could be that the school is dominantly practiced in the country by the people as well as the government. The evidence can be clearly seen in the inscriptions on the historic stone of Terengganu, the Canon law of Melaka and other laws that came later. Though there's no mention of the Shafi'ite school in the laws, their provisions were clearly based on the views of the school. The same can be seen in the current enactments of Islamic Laws of the various states of Malaysia. Judges in the Syariah Courts do not bind themselves to any of the schools including the Shafi ite school. However, in terms of fatwas, the views of Shafi'ite school are still dominant.
\end{abstract}

* Prof. Madya, Jabatan Fiqh \& Usul, Akademi Pengajian Islam, Universiti Malaya, Kuala Lumpur. 


\section{PENDAHULUAN}

Yang dimaksudkan dengan Undang-Undang Jenayah Islam di Malaysia ialah peruntukan-peruntukan tentang hukum jenayah Islam di bawah kuasa-kuasa Mahkamah Syariah di negeri-negeri di Malaysia. Sebagaimana maklum, di Malaysia kuasa-kuasa pelaksanaan Undang-Undang Islam, termasuk dalam perkara jenayah terletak di bawah kuasa negeri. ${ }^{1}$ Berasaskan kepada kuasa berkenaan negeri-negeri di Malaysia telah menubuhkan Mahkamah Syariah masing-masing dan mengkanunkan undangundang Islam dalam banyak perkara, termasuk perkara-perkara mengenai jenayah.

Yang dimaksudkan dengan hukum jenayah pula ialah ketentuan syariat Islam tentang kesalahan jenayah dan hukuman yang perlu dikenakan keatas pesalah berkenaan. Dalam pengajian hukum Islam "jenayah" biasanya diertikan sebagai kesalahan yang boleh dihukum dengan kesiksaan tertentu. Kata al-Mawardi, ia adalah larangan syarak yang dicegah oleh Allah dengan (hukuman) had atau takzir. $^{2}$

Definisi ini penting dalam menentukan perbezaan antara "kesalahan jenayah" dan "kesalahan sivil". Mengikut para fuqaha, kesalahan jenayah secara umumnya dikenakan hukuman bersifat kesiksaan, sementara dalam kesalahan sivil hukuman yang dikenakan secara umumnya bersifat ganti rugi ${ }^{3}$

Walau bagaimanapun, penggunaan istilah "jenayah" dalam konsepnya yang umum seperti mana di atas tidak begitu popular dikalangan para fuqaha' klasik Islam. Mereka lebih biasa menggunakan istilah-istilah yang lebih khusus, iaitu hudud, qisas dan takzir dengan secara terpisah. Dengan kata lain, mereka kurang menggunakan istilah "kesalahan jenayah" secara umum tetapi sebaliknya menggunakan istilah lebih terperinci dengan memecahkan konsep "jenayah" itu kepada tiga komponen yang

\footnotetext{
1 Perlembagaan Malaysia, Jadual Kesembilan Senarai 2 - senarai negeri

2 Al-Māwardī (1978), al-Aḥkām al-Sulțāniyyah. Beirut: Dār al-Kutub al-'Ilmiyyah, h. 219.

3 Lihat: 'Abd al-Qādīir 'Audah (1968), al-Tasyri' al-Jinā'i, j. 1. Kaherah: (t.t.p.), h. 66.
} 
lebih kecil, iaitu "kesalahan hudud", "kesalahan qisas" dan "kesalahan takzir". ${ }^{4}$

Kesalahan hudud bererti kesalahan yang boleh dihukum dengan hukuman hudud. Mengikut pendapat jumhur fuqaha ${ }^{65}$ kesalahan hudud adalah terdiri daripada kesalahan-kesalahan berzina, mencuri, meminum arak, menuduh zina (qadhaf), menyamun, memberontak, dan murtad.

Kesalahan qisas pula ialah kesalahan yang boleh dihukunm dengan hukuman qisas. Mengikut para fuqaha ${ }^{6}$, kesalahan qisas adalah kesalahan terhadap nyawa dan tubuh badan manusia. Secara terperincinya ia boleh dikategorikan sebagai berikut:

1. Kesalahan terhadap nyawa, iaitu membunuh

2. Kesalahan terhadap tubuh badan, iaitu meluka atau mencederakan

3. Kesalahan terhadap nyawa daripada satu aspek dan tubuh badan daripada satu aspek yang lain, iaitu kesalahan terhadap anak dalam kandungan

Di samping itu ada satu hukuman lain bagi kesalahan seperti ini, iaitu diyat. Ia adalah hukuman alternatif apabila hukuman qisas tidak boleh dilaksanakan oleh sebab-sebab tertentu, seperti apabila jenayah itu sendiri berlaku tidak sengaja atau separuh sengaja, ataupun apabila hukuman qisas tidak dapat dilaksanakan oleh sebab-sebab material, seperti tiada persamaan di antara penjenayah dan mangsa, atau semata-mata kerana pihak mangsa tidak mahu melaksanakan qisas dan memilih diyat sebagai ganti.

4 Lihat misalnya: Ibn Qudāmah (1994), al-Mughnī, j. 8 \& 9. Beirut: Dār al-Kutub al-'Ilmìyyah.

5 Lihat: 'Abd al-Qādir 'Audah (1968), op.cit., j. 2, h. 345; Muhammad Sālim al-'Awwa (1979), Fī Usūl al-Nižām al-Jinā'î. Kaherah: Dār al-Ma'ārif, h. 159.

6 Lihat: 'Abd al-Qādìr 'Audah (1968), op.cit., j. 2, h.5; Muhammad Abū Zahrah (t.t.), al-Jarimah Wa al- 'Uqūbah, j. 1. Kaherah: Dār alFikr al-'Arabi, h. 104. 
Manakala kesalahan takzir pula ialah kesalahan yang boleh dihukum dengan hukuman takzir . Kesalahan ini telah dikelaskan oleh para fuqaha' ${ }^{7}$ kepada beberapa ketegori, iaitu:

1. Perbuatan maksiat, iaitu yang diharamkan oleh Syarak

2. Perbuatan yang bertentangan dengan kepentingan awam,

3. Perbuatan atau tinggalan yang tidak wajar, iaitu bertentangan dengan sifat-sifat murni.

Dalam penulisan ini, istilah "jenayah" dalam konsepnya yang umum akan digunakan, kecuali apabila perlu mana-mana kategori tadi disebut.

\section{LATAR BELAKANG SEJARAH}

Kenyataan paling awal tentang pelaksanaan undang-undang jenayah Islam di Malaysia ialah catatan di batu bersurat yang ditemui di Kuala Berang Terengganu dalam tahun 1898 M. Inskripsi tersebut bertarikh pada 17 Rejab $702 \mathrm{H}$, iaitu bersamaan dengan 22 Febuari 1303M. Catatan tersebut ialah mengenai kesalahan dan hukuman terhadap jenayah zina. Ia menyatakan:

"Orang berbuat balacara lelaki perempuan setitik; Dewata Mulia Raya jika mereka bujang palu; seratus rotan. Jika mereka merdeka beristeri; atau perempuan bersuami ditanam hinggakan; pinggang dikembalang dengan batu matikan"

Meskipun tidak ada catatan lain yang boleh memberi kenyataan tentang pelaksanaan sebenar undang-undang zina tersebut dalam masyarakat pada waktu itu, namun boleh diandaikan ia telah dilaksanakan. Kerana kenyataan yang menunjukkan ianya tidak dilaksanakan juga tidak ada. Kalau diandaikan ianya tidak dilaksanakan bererti suatu keraguan telah dibuat terhadap kesungguhan masyarakat Islam pada waktu itu dalam beragama, iaitu suatu anggapan yang tidak mempunyai apa-apa asas.

Kenyataan yang lebih terkemudian ialah yang terdapat dalam Undang-Undang Melaka, iaitu undang-undang yang ditulis sekitar

'Abd al-Qādīir 'Audah (1968), ibid., j. 1, h. 128. 
tahun 1523-1524, iaitu pada zaman pemerintahan Sultan Mahmud Syah. ${ }^{8}$

Peruntukan tentang jenayah dalam undang-undang tersebut terbahagi kepada hudud, qisas, diyat dan takzir, iaitu sama dengan pembahagian yang terdapat dalam pengajian hukum Islam.

Berkenaan dengan hudud, undang-undang tersebut memperuntukkan beberapa peruntukan tentang jenayah zina, menuduh zina (qadzaf), murtad, mencuri, meminum arak, menderhakai pemerintah dan menyamun.

Berkenaan dengan qisas pula undang-undang tersebut memperuntukkan hukuman qisas bagi kes membunuh dan mencederakan. Mengenai diyat terdapat peruntukan tentang kewajipan membayar diyat dalam kes membunuh dan mencederakan dengan tidak sengaja.

Sementara peruntukan tentang takzir pula terdapat dalam keskes bersyubahat dalam kesalahan mencuri, kesalahan seks yang tidak mencapai tahap perzinaan yang boleh dikenakan had hudud, berdusta terhadap bendahara, dan mmemberi kesaksian palsu.

Selain dalam Undang-Undang Melaka, pelaksanaan undangundang jenayah Islam ini juga dapat dilihat dalam kanun-kanun yang lain yang terdapat di Malaysia sebelum zaman penjajahan. Dalam Undang-Undang Pahang9, yang ditulis pada zaman pemerintahan sultan Abdul Ghafar Mahaiyuddin Shah, yang memerintah di antara tahun 1592 hingga 1616, misalnya terdapat berbagai peruntukan tentang jenayah. Antaranya ialah yang berkenaan dengan hukum qisas, hudud, diyat dan takzir.

Begitulah juga dalam Undang-Undang Johor yang dibuat pada tahun1203H (1788/9M), iaitu pada zaman pemerintahan Sultan Mahmud al-Ghazi Ibn Abdul Jalil Shah ${ }^{10}$. Hal yang sama juga terdapat dalam Undang-Undang Kedah yang ditulis pada tahun

\footnotetext{
8 Lihat: Liaw Yock Fang (1976),Undang-Undang Melaka. The Hague: Martinus Nijhoff.

9 R.O.Winstedt \& John E. Kempe (1948) “A Malay Legal Digest” dlm. JMBRAS, Vol. xxi, Part 1.

10 Liaw Yock Fang (1976), op.cit., h. 37.
} 
1211H (1893M $)^{11}$, dan Undang-Undang Sembilan Puluh Sembilan Perak. $^{12}$

Mengikut kepercayaan umum, pelaksanaan undang-undang Islam, termasuk dalam kes-kes jenayah di Melaka dan semua negeri-negeri di Malaysia masih diteruskan sehingga berlaku penjajahan Inggeris pada tahun 1786. Mengikut kepercayaan itu, Portugis yang mula menakluk Melaka pada tahun 1511, dan kemudiannya Belanda yang menjajah negeri-negeri di Malaysia tidak berminat untuk memperkenalkan undang-undang mereka di Malaysia pada waktu penjajahan mereka. ${ }^{13}$

Di bawah pengaruh penjajahan Inggeris, Undang-Undang Islam, termasuk juga hal-hal jenayah yang dulunya dilaksanakan sebagai Undang-Undang Negara telah tersingkir sedikit demi sedikit bermula daripada langkah Inggeris memperkenalkan Piagam Keadilan Pertama pada tahun 1807 sampailah kepada tahun 1956 apabila Ordinan Undang-Undang Sivil 1956 diperkenalkan. Dengan langkah-langkah seperti itu Inggeris telah menyisihkan Undang-Undang Islam yang dahulunya merupakan undangundang negara hingga menjadi undang-undang yang terbatas kepada hal-hal nikah cerai dan seumpamanya dengan ditadbir oleh mahkamah kadhi atau disebut kemudiannya sebagai mahkamahmahkamah Syariah dalam pengertiannya yang terbatas.

Berasaskan kepada kedudukan inilah mahkamah-mahkamah Syariah tidak diletakkan di bawah kuasa-kuasa persekutuan, tetapi sebaliknya di bawah kuasa-kuasa negeri. Maka berasaskan kedudukan ini, sampai ke hari ini Mahkamah Syariah merupakan Mahkamah Agama dalam pengertian yang sekular. Dalam kedudukannya seperti ini ia mempunyai skop dan bidangkuasa

11 Kodin bin Komis, Undang-Undang Kedah., K/PU 1 Arkib Negara, Kuala Lumpur.

12 Lihat: R. J. Wilkinson (1908), The Ninty-Nune Law of Perak, dlm: J Rigby (ed.) Papers on Malay Subject, Kuala Lumpur: The Government of the Federated Malay States Press, Part II.

13 Lihat: Ahmad Ibrahim dan Ahilemah Joned (1985), Sistem UndangUndang Di Malaysia. Kuala Lumpur: Dewan Bahasa dan Pustaka, h. 14. ; Wu Min Aun (1985), Pengenalan Kepada Sistem Perundangan Malaysia, ed. 3. Kuala Lumpur: Heinemann Educational Book, h. 4. 
yang sempit dan terbatas sepertimana yang terdapat dalam enakmen-enakmen yang tersebut di atas dan beberapa enakmen lain yang menyentuh persoalan kekeluargaan dan perkara Mal.

\section{UNDANG-UNDANG JENAYAH ISLAM DI MALAYSIA}

Antara undang-undang terawal diperkenalkan mengenai jenayah ini di Malaysia di bawah pengaruh undang-undang Inggeris ialah Adultery by Muhammadan yang dikuatkuasakan di Perak melalui perintah no.1 tahun 1894. Undang-undang yang serupa juga dikuatkuasakan di Selangor pada tahun yang sama dan dikenali sebagai The Prevention of Adultery Regulation ${ }^{14}$

Selepas itu The Muhammadan Laws Enactment 1904 dikuatkuasakan di Negeri-negeri Melayu Bersekutu, iaitu Perak ${ }^{15}$, Selangor ${ }^{16}$, Negeri Sembilan ${ }^{17}$, dan Pahang ${ }^{18}$. Undang-undang ini bertujuan untuk menghukum orang Islam yang melakukan kesalahan tertentu. Berbagai pindaan kemudiannya telah dibuat terhadap undang-undang ini di negeri-negeri berkenaan sehinggalah diletakkan di bawah Chapter 198 Revised Law of Federated Malay States 1935.

Di Kelantan pada tahun 1915 telah dikuatkuasakan undangundang untuk menghukum orang minum arak dan tidak berpuasa. Undang-Undang tersebut dikenali dengan The Notice of Muhammadans : Prohibation of Intexicating Liquor and Rules of Fasting 1915 yang dikuatkuasakan melalui nitis no.12 tahun 1915.

Terkemudian ialah Undang-Undang Mahkamah Syariah 1337H(1918) yang dikuatkuasakan di Kedah. Undang-undang ini sebenarnya bukan sahaja mengandungi peruntukan tentang jenayah tetapi juga kekeluargaan dan harta. Ia dikuatkuasakan

\footnotetext{
14 Lihat: Federated Malay Stats (1935), State and Fedral Law(Index) 1877-1934. Kuala Lumpur: Federated Malay State Press.

15 Enactment no. 2 tahun 1904.

16 Enactment no. 3 tahun 1904.

17 Enactment no. 6 tahun 1904.

18 Enactment no. 2 tahun 1904.
} 
melalui undang-undang no. 9 tahun 1337H.(1918). Pada tahun 1919 Johor menguatkuasakan The Offences By Muyhammadan Enactment 1919 melalui enakmen no. 25 tahun 1919. Sementara di Terengganu pula dikuatkuasakan Undang-Undang Tegahan Berkhalwat melalui Enakmen no.3 tahun 1342H (1923).

Pada tahun 1938 Kelantan menguatkuasakan satu undangundang yang lebih lengkap daripada yang terdahulu di bawah nama The Muhammadan Offences Enactment 1938, iaitu melalui enakmen no.21 tahun 1938. Pada tahun yang sama juga Selangor, Negeri Sembilan dan Pahang menguatkuasakan undang-undang yang serupa juga di bawah nama Muhammadan( Offences) Enacement 1938. Perak turut menguatkuasakan undang-undang yang sama pada tahun 1939. Undang-Undang yang dikuatkauasakn di Negeri-negeri Melayu Bersekutu itu memansuhkan Chapter 198, Revised Law of Federated Malay States 1935 seperti yang tersebut di atas.

Apabila negeri-negeri di Malaysia menguatkuasakan undangundang pentadbiran hukum Islam bagi negeri masing-masing, perkara jenayah ini menjadi sebahagian daripada undang-undang tersebut, iaitu:

1. Enakmen Pentadbiran Hukum Syarak Selangor 1952

2. Enakmen Pentadbiran Undang-Undang Islam, Terengganu 1955

3. Enakmen Pentadbiran Undang-Undang Islam Pahang 1956

4. Enakmen Pentadbiran Undang-Undang Islam Melaka 1959

5. Enakmen Pentadbiran Undang-Undang Islam Pulau Pinang 1959

6. Enakmen Pentadbiran Undang-Undang Islam Negeri Sembilan 1960

7. Enakmen Pentadbiran Undang-Undang Islam Kedah 1962

8. Enakmen Pentadbiran Undang-Undang Islam Perlis 1964

9. Enakmen Pentadbiran UndangUndang Islam Perak 1965

10. Undang-Undang Mahkamah Syariah dan Hal Ehwal Perkahwinan Islam Kelantan 1966, dan Undang-Undang 
Majlis Ugama Islam dan Adat Istiadat Melayu Kelantan 1966

11. Ordinan Majlis Islam(Penubuhan) Sarawak 1977

12. Enakmen Pentadbiran HukumSyarak Sabah 1977

13. Enakmen Pentadbiran Agama Islam Johor 1978

14. EnakmenPentadbiran Hukum Syara' Wilayah Persekutuan 1974

Apabila pemecahan semula dibuat diantara klompok-klompok undang-undang Islam di Malaysia, masing-masing menjadi undang-undang tersendiri. Hal-hal berkenaan dengan jenayah ini diperuntukkan di bawah enakmen kanun jenayah Syari'ah masing-masing negeri, iaitu seperti berikut:

1. Enakmen Kanun Jenayah Syariah Negeri Kelantan 1985

2. Enakmen Kanun Jenayah Syariah Negeri Kedah 1988

3. Enakmen Kesalahan Jenayah Syariah Negeri Melaka 1991

4. Enakmen Jenayah Syara' Negeri Perlis 1991

5. Enakmen Kesalahan Jenayah Negeri Melaka 1991

6. Ordinan Kesalahan Jenayah Syariah Negeri Sarawak 1991

7. Enakmen Jenayah Syariah Negeri Perak 1992

8. Enakmen Jenayah Syariah Negeri Sembilan 1992

Berasaskan peruntukan dalam undang-undang di atas kuasakuasa Mahkamah Syariah di Malaysia dalam bidang jenayah boleh dirumuskan seperti berikut:

1. Kesalahan-kesalahan berhubung dengan akhlak, seperti berkelakuan tidak sopan dan lelaki berlagak seperti perempuan di tempat-tempat awam

2. Kesalahan-kesalahan seks, seperti bercumbuan di antara bukan suami isteri, bersekedudukan atau berkhalwat, berkelakuan sumbang, berzina, melakukan mukaddimah zina, liwat, musāhaqah, hamil atau melahirkan anak di luar nikah dan melacurkan diri. 
3. Kesalahan-kesalahan berhubung dengan amalan agama, seperti mengluarkan atau menyebarkan kata-kata yang bertentangan dengan hukum Syarak, menganjur, mengalakkan atau melakukan maksiat, meminum minuman yang memabukkan, menjual dan membeli minuman yang memabukkan dan tidak berpuasa pada bulan Ramadhān.

4. Kesalahan-kesalahan berhubung dengan kesejahteraan orang lain, seperti menghasut atau memujuk mana-mana perempuan yang bersuami atau lelaki yang beristeri supaya bercerai, melarikan atau menyebabkan seorang isteri orang lain meninggalkan rumahtangga yang ditentukan oleh suaminya, melacurkan anak atau kanak-kanak di bawah jagaan, melarikan atau mempengaruhi seorang perempuan supaya lari daripada jagaan ibu bapanya, menjual atau menyerahkan kanak-kanak di bawah jagaan kepada seorang yang bukan Islam, menjadi muncikari dan mempertikai keIslaman orang lain.

5. Kesalahan berkait dengan pentadbiran hukum Islam, seperti mengingkari, membantah, melanggar atau mengeji mana-mana kadi atau pegawai Hal-Ehwal agama Islam, menghina mana-mana undang-undang yang berkuatkuasa di Mahkamah, melanggar dan mengingkari atau menghina mana-mana perintah mahkamah.

6. Bersubahat dalam melakukan apa-apa kesalahan di atas.

\section{ANALISIS KEDUDUKAN MAZHAB SYAFI'I}

Tidak seperti dalam masalah fatwa, tiada apa-apa peruntukan dalam mana-mana undang-undang pentadbiran Mahkamah Syariah yang menentukan bahawa mazhab Syafi‘i mesti diikuti samada dalam menentukan peruntukan undang-undang ataupun dalam menentukan hukuman dalam mana-mana perbicaraan.

Hakikat ini ternyata dalam semua teks yang ada bermula daripada batu surat di Kuala Berang, Terengganu sehingalah kepada enakmen-enakmen terbaru bagi jenayah Syariah yang dikuatkuasakan di negeri-negeri pada hari ini. Dalam Enakmen Kanun Jenayah Syariah negeri Kelantan 1985 misalnya rujukan 
dibuat kepada "Hukum Syarak" secara umum apabila peruntukanperuntukan mengenai kesalahan jenayah yang boleh dihukum di bawah undang-undang tersebut seperti perbuatan tidak sopan ${ }^{19}$, perkataan tidak sopan ${ }^{20}$, zina yang tidak boleh dikenakan hukuman hudud $^{21}$, liwat yang tidak boleh dikenakan hukuman hudud ${ }^{22}$, dan meminum arak yang tidak boleh dikenakan hudud ${ }^{23}$

Hal yang sama juga terdapat dalam Undang-Undang Pentadbiran Jenayah Syariah yang lain, misalnya Kanun Jenayah Syariah Negeri Kedah 1988, iaitu di bawah peruntukan-peruntukan mengenai perbuatan tidak $\operatorname{sopan}^{24}$ dan perkataan tidak sopan ${ }^{25}$

Malah dalam hal-hal apabila berlaku percanggahan pendapat tentang mentafsir sesuatu perkataan, perbahasan atau rangkai kata mengenai hukum Syarak yang dimaksudkan oleh akta-akta berkenaan maka kuasa mentafsirnya terserah kepada Mahkamah yang membicarakan kes berkenaan ${ }^{26}$, iaitu tanpa terikat dengan mana-mana mazhab, termasuk mazhab Syafi'i.

Walau bagaimanapun, berasaskan kepada peruntukan sebenar dalam teks-teks berkenaan ternyata mazhab Syafi'i menjadi asas kepada peruntukan-peruntukan tersebut. Ini berasaskan kepada tiada peruntukan dalam teks-teks berkenaan yang bersalahan dengan pendapat dalam mazhab Syafi'i. Malah dalam kes-kes di mana ada perbezaan pendapat peruntukan berkenaan selalunya berasaskan kepada pandangan mazhab Syafi'i. Antara contoh kepada kedudukan berkenaan adalah seperti berikut:

1. Dalam Hukum Kanun Melaka ${ }^{27}$, perbuatan liwat dikategorikan sebagai zina. Ini merupakan huraian yang sesuai

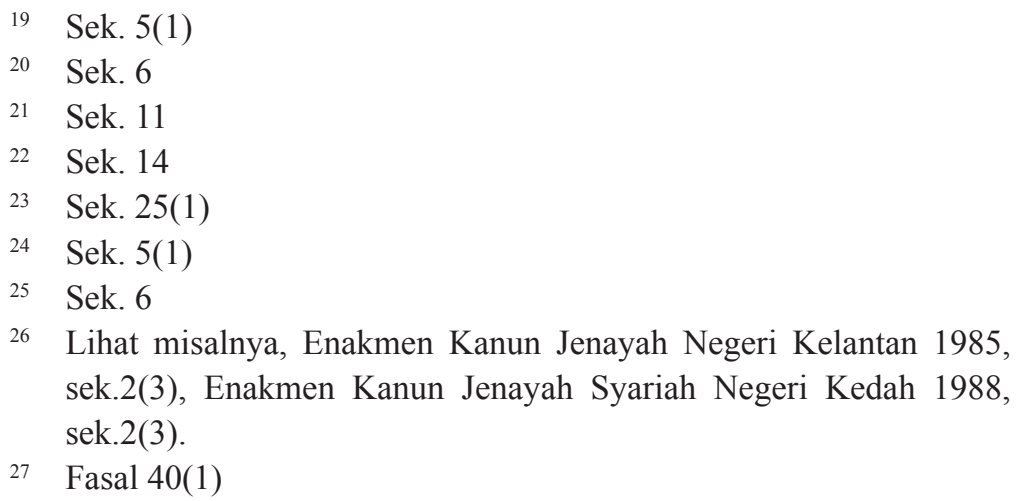

26 Lihat misalnya, Enakmen Kanun Jenayah Negeri Kelantan 1985, sek.2(3), Enakmen Kanun Jenayah Syariah Negeri Kedah 1988, sek.2(3).

27 Fasal 40(1) 
dengan pandangan mazhab Syafi' $\mathrm{i}$ yang berasaskan hadith riwayat al-Khamsah, kecuali al-Nasā'i daripada 'Ikrimah daripada Ibn 'Abbās, dan hadith Abū Dāud daripada Sa'id Ibn Jābir dan Mujāhid daripada Ibn 'Abbās ${ }^{28}$.

Keadaan yang sama juga terdapat dalam Enakmen Kanun Jenayah Syariah yang terlaksana di Malaysia sekarang, misalnya dalam Kanun Jenayah Syariah Negeri Kelantan 1985 yang menyebut tentang liwat yang tidak boleh dikenakan hukuman hudud ${ }^{29}$. Maksudnya, secara mafhum, kesalahan meliwat di kategorikan oleh undangundang tersebut sebagai kesalahan zina sepertimana yang dihuraikan di atas.

2. Konsep arak yang terdapat dalam Hukum Kanun Melaka ${ }^{30}$ berasaskan kepada pandangan mazhab Syafi'i, iaitu termasuk semua minuman yang memabukkan ${ }^{31}$. Pendirian yang sama juga terdapat dalam undang-undang jenayah Syariah yang dilaksanakan di Malaysia sekarang. ${ }^{32}$

Satu perkara lain yang boleh diambil kira dalam menentukan kedudukan mazhab Syafi'i dalam undang-undang jenayah Islam di Malaysia ini ialah keputusan yang dibuat oleh para hakim mahkamah berkenaan mengenai kes-kes yang dibicarakan di bawah peruntukan-peruntukan berkenaan. Secara umumnya apa yang dapat diperhatikan daripada keputusan-keputusan tersebut tiada rujukan dibuat kepada mazhab, termasuk mazhab Syafi'i. Apa yang ada hanyalah rujukan kepada "hukum Islam" secara umum sahaja.

28 Lihat: al-Syawkāni, ibid., h. 286.

29 Sek. 14

30 Fasal 42

31 Lihat huraian tentang pandangan mazhab tersebut dalam : al-Sya bini al-Khatịib (1958), Mughni al-Muhtāj, j. 4. Kaherah: al-Halabī, h. 186.

32 Sebagai contoh: Lihat Enakmen Kanun Jenayah Syariah Negeri K lantan 1985, Sek. 25(1); Enakmen Kanun Jenayah Negeri Kedah 1988, Sek. 25(1). 
Dalam Halimah v. Pendakwa Jenayah Kelantan (Kes Rayuan Jenayah no.2, 1979$)^{33}$, Timbalan Kadhi Besar, Haji Mustafa Haji Idris dalam keputusannya membuang kes dakwaan berkenaan, antara lain menyebut bahawa keterangan saksi-saksi dalam kes berkenaan "tidak mencukupi dan tidak memenuhi bagaimana syarat-syarat bab al-Syahādah di dalam kitab fekah", iaitu tanpa merujuk kepada mana-mana mazhab, termasuk kitab dalam mazhab Syafi'i. Hukuman tersebut kemudiannya dikukuhkan oleh Jemaah pengadilan yang dipengurusikan oleh Haji Ismail Haji Yusuf, pemangku mufti.

Dalam Abdul Wahab lwn. Timbalan Pendakwa Mahkamah Syariah Selangor (Kes Ulang Bicara Jenayah Bill/1973) ${ }^{34}$ Jawatankuasa ulang bicara yang dipengurusikan oleh Hakim Haji Mohamed Azmi bin Dato Haji Kamaruddin, dalam membatalkan keputusan Mahkamah Kadhi Besar yang menjatuhkan hukuman penjara selama 30 hari keatas tertuduh kerana berkhalwat, mempersoalkan kewajaran hukuman tersebut berasaskan kepentingan umum dan realiti buruk laku yang terdapat dalam masyarakat secara umum. Dengan lain perkataan, rujukan telah dibuat kepada prinsip Mașlaha dan 'Urf secara umum tanpa merujuk kepada pandangan mazhab secara khusus, termasuk mazhab Syafi‘i.

Dalam Pendakwa Mahkamah Syariah Perak lwn. Fatimah (Mahkamah Kadhi Kuala Kangsar, kes jenayah bil. 45/79) ${ }^{35}$, Kadhi Besar, Haji Abdul Malik bin Nordin dalam hujah penghakimannya menjatuhkan hukuman terhadap tertuduh menyebut bahawa "...mengandung dan melahirkan anak adalah bukti berlakunya persetubuhan dengan seorang lelaki.", iaitu suatu pandangan yang tidak mempunyai asas dalam mazhab Syafi'i.

Ketiga-tiga kes contoh di atas yang diambil secara rawak daripada kes-kes yang dilaporkan dalam Jurnal Hukum menunjukkan bahawa tidak ada rujukan yang konsisten terhadap mazhab Syafi' i dalam melakukan keputusan dalam kes-kes jenayah Syariah di mahkamah-mahkamah Syariah di Malaysia. Dalam kes

33 Kelantan Kes Rayuan Jenayah no. 2/1979 . Jurnal Hukum, Rejab 1401/Mei 1981, j. 1, bhg. ii, hh. 52-62.

34 Jurnal Hukum, Rejab 1402/Mei 1982, j. 2, bhg. 2, hh. 281- 285.

35 Jurnal Hukum, Syawal 1407/Jun 1987, j. 5, bhg. 2, hh.321-325. 
pertama di atas, rujukan telah dibuat kepada hukum fekah secara umum. Dalam kes kedua prinsinp Mașlaha dan 'Urf secara umum telah digunakan, iatu sesuatu yang tidak konsisten secara rasminya dengan mazhab Syafi'i. Sementara dalam kes ketiga pula alasan yang diberikan bagi keputusan berkenaan bertentangan secara jelas dengan pendirian mazhab Syafi' $i$, iaitu menerima qarinah dalam mensabitkan kes zina.

\section{PENUTUP}

Persoalan utama dalam kertas ini ialah apakah mazhab Syafi'i telah diikuti secara konsisten atau sebaliknya dalam pentadbiran undang-undang jenayah Islam di Malaysia? Jawapan secara umumnya, tidak. Walau bagaimanapun kecenderungan secara umum untuk beriltizam dengan pendapat mazhab berkenaan agak ketara terutama melalui peruntukan-peruntukan dalam teks-teks undang-undang berkenaan. Hal ini boleh menjadi asas kepada kesimpulan bahawa mazhab Syafi' ${ }^{i}$ masih lagi diamalkan dengan secara meluas walaupun kurang teratur dalam undang-undang jenayah Syariah di Malaysia sekarang.

Sehubungan dengan hal ini, adalah wajar dibangkitkan tentang soal bagaimana pandangan mazhab ini boleh dikembangkan melalui perbahasan di Mahkamah terutama oleh para peguam Syar'i. Untuk itu budaya berhujah secara lebih mendalam dengan menggunakan hasil penulisan dalam perbendaharaan fiqh yang ada, termasuk yang dikelaskan sebagai klasik adalah sangat berfaedah. Malang sekali budaya seperti itu tidak terdapat di mahklamahmahkamah Syariah di Malaysia sekarang, sepertimana yang dapat dirasakan melalui apa yang terdapat dalam laporan kes sepertimana yang termuat dalam Jurnal Hukum. 